\title{
Implementation of Credit Restructuring Provisions for Debtors of Non-Performing Loans in Bank Credits
}

\author{
I Dewa Gede Indra Eka Putra ${ }^{1}$, I Nyoman Putu Budiartha ${ }^{2}$ and I Nyoman Sujana ${ }^{3}$ \\ \{Indra_putra@gmail.com, budiartha59@gmail.com and nyoman_sujana@yahoo.com\} \\ Universitas Warmadewa, Denpasar, Bali-Indonesia
}

\begin{abstract}
Indonesia government's effort made to overcome the high increase of nonperforming loan is issuing policy in the form of Bank Indonesia Regulation No. 2/15/PBI/2000 concerning Credit Restructuring in the form of a reduction in loan interest rates, extension of credit period, reduction of interest credit arrears, reduction of loan principal arrears, addition of credit facilities, and conversion of credit to temporary capital participation. Empirically, barriers to implementing this strategy still occur: obstacles in the process, obstacles to implementation, and obstacles to legal factors. With an Indonesian legal perspective approach, the study examines the application of strategies to find alternative solutions by applying empirical legal research methods. The results show that deviations in applying credit restructuring provisions are the leading factors that hinder their success, aside from amendments to the provisions that occur. Amendments must be reduced and prospective debtors should gain an in-depth understanding of the system in credit.
\end{abstract}

Keywords: Credit bank; credit restructuring; non-performing loans

\section{Introduction}

The development of the banking world in Indonesia is now getting better. Various financial services have been developed to provide comfort for the community [1]. This supports the situation that the bank's main function is to raise funds from the public and redistribute to the community for various purposes; or the bank itself is a financial intermediary [2,3]. In addition, in the Law of the Republic of Indonesia Number 10 of 1998 concerning Amendments to Law Number 7 of 1992 concerning Banking (Banking Law) Article 1 number 1, said "Banking is everything that concerns banks, includes institutions, business activities, and ways and the process of carrying out its business activities". One form of channeling funds from banks to the public is crediting [4]. Credit in the perspective of the Indonesian Law on Banking Article 1 number 11 is the provision of money or bills that are identical to that based on a loan agreement between the bank and another party that promises the borrower to repay the debt after a certain period of time with interest. Hence, giving credit is a very basic activity of a bank [5].

In reality, credit distribution has a very large risk and a significant impact that occurs as a result of some debtors not fulfilling something required as stipulated in an agreement or contract or default, which has decreased in credit payments or often referred to as non-performing loan (NPL). The high NPL ratio has a negative impact on bank performance progress. To overcome this 
condition, the Indonesian government collaborated with the bank to make an effort to reduce the NPL by issuing a Decree of the Board of Directors of Bank Indonesia No. 31/150/KEP/DIR on 12 November 1998 concerning Credit Restructuring, which was subsequently amended into Bank Indonesia Regulation No. 2/15/PBI/2000 concerning Credit Restructuring. This restructuring is a bank program as an improvement effort carried out in credit activities with debtors who have difficulty fulfilling their obligations [6]. In the Decree, it is stated that Credit Restructuring can be carried out in 7 ways, namely: reduction in interest rates, reduction of loan interest arrears, reduction of loan principal arrears, extension of credit period, addition of credit facilities, acquisition of debtor assets in accordance with applicable regulations, and conversion of loans to temporary capital participation in debtor companies. Notwithstanding, in provisions issued by the government, a bank can only conduct credit restructuring for debtors who meet the following criteria: (1) Debtors have difficulties in repaying loan principal and/or interest; and (2) Debtors have good business prospects and are able to fulfill obligations after the loan is restructured.

Studies on financial restructuring have been released in an unlimited number and with various context and locus by scholars and researchers. Financial restructuring and credit unions nature was once examined determine their implications to the society [7]. A review on Distressed debt restructuring in the presence of credit default swaps was ever conducted by looking at the debt restructurings (distressed exchanges and bankruptcy filings of rated, nonfinancial U.S. companies over a certain 4-years period [8]. It was obtained that firms where empty creditors are more likely to emerge are not characterized by a higher probability of filing for bankruptcy than other firm. In conjunction with the objective of the present study, implementation of credit restructuring law provisions was once explored by in a previous study in Indonesia [9]. It was revealed that implementation of the provisions of the rescue loan restructuring and settlement of nonperforming loans on bank credit has not been optimally applied to all borrowers who are having trouble paying even though they have the opportunity to carry out the payment. Restructuring in credits seems to be in emerging problem that debiturs like firms are likely to be recommended to it because it have proven resulting in credit crunch and crisis [10]. Instead, the credit restructuring had been widely applied in bank credits throughout Indonesia territory and is protected by law.

This study examines the implementation of credit restructuring provisions in the redemption and completion of Non-Performing Loans in bank credits and identifies the obstacles faced in implementing the loan restructuring provisions in question using recommend alternative solutions.

This study was designed with the application of empirical methods that move from the gap between das solen and das sein by using. We make benefits from statute approach [11], case approach, and sociological approach. The data of this study were collected by observation method at PT. Bank Panin Tbk, KCU Kuta-Bali and interview with the director, the manager and 5 customers of the company. In addition, we collected theories relating to banking and credit restructuring from various results of previous studies and at the same time we compiled articles of Indonesian law governing banking and credit restructuring. Data processing is done qualitatively and is presented in the form of a description.

\section{Results and Discussion}




\subsection{Implementation of Provisions on Credit Restructuring for Non-Performing Loan Debtors}

Normative restructuring policies are only given to debtors who have difficulties in fulfilling their obligations rather than debtors who deliberately do not pay because of bad intentions. According to a decree letter from the Board of Directors of Bank Indonesia No. 31/147/KEP/DIR concerning Earning Asset Quality on 12 November 1998, credit risk for derivative transactions is the mark to market value of all agreement/contract that allow benefits that cannot yet be realized but can potentially be a loss for bank if the other party defaults.

Determination of credit risk is an attempt to anticipate the bank for losses caused by nonperforming loans, even in current loans, credit risk still exists. The high rate of non-performing loans must be anticipated by reserving creditors' risk. According to Faure in his book entitled "Banking: An Introduction "meyatakan", credit risk is the risk that the borrower from a bank will default on the loan and/or the interest payable [12]." Credit risk is the risk that the borrower from the bank will not be able to repay the loan and/or or not be able to pay the interest to be paid. In dealing with this risk, Bank Indonesia issued a policy regarding restructuring. Restructuring can be done with or without rescheduling and/or reconditioning based on Circular Letter No. 15/28/DPNP to all Commercial Banks. The credit restructuring is carried out in accordance with the prudential principles and applicable Financial Accounting Standards.

Restructuring is a step that must be carried out jointly by creditors and debtors if a nonperforming loan occurs. Credit restructuring is very easy to do as long as there is good faith from the customer as the debtor, and the good faith in question is [13]:

good faith is an intangible and abstract quality with no technical meaning or statutory definition, and it compasses, among other things, an honest belief, the absence of malice and the absence of design to defraud or to seek an unconscionable advantage, and individual's personal good faith is concept of his own mind and inner spirit and, therefore, may not conclusively be determinded by his protestations alone in common usage this term is ordinarily used to describe that state of mind denoting honesty of purpose, freedom from intention to defraud, and, generally speaking, means being faithful to one's duty or obligation.

However, not all non-performing loans can be restructured [14]. Thus, basically restructuring can be carried out on any bad credit regardless of whether the debtor is a big businessman or small businessman [15]. Restructuring can be done if the debtor does experience a decline in the ability to pay and is still able to pay, not due to bad faith [14]. Credit restructuring can only be carried out on the basis of a written application from a customer with a substandard, doubtful and congested credit quality category. The Bank may conduct debtor debt restructuring that still has business prospects and ability to pay while still observing prudential principles and Financial Accounting Standards [16].

In terms of benefits, the credit restructuring policy is useful to ensure banking health as regulated in Article 53 of Bank Indonesia Regulation Number 14/15/PBI/2012 concerning Asset Quality Evaluation for Commercial Banks which are prohibited from restructuring loans with the aim of improving credit quality, or to avoid increasing the formation of Asset Allowance without regard to the criteria of the debtor as referred to in Article 52.

In the issued provisions, each bank is obligated to apply the Credit Restructuring Accounting in accordance with the applicable Financial Accounting Standards. Accounting for credit restructuring is intended to obtain recognition of losses incurred, interest and other incomes. In the context of the implementation of the precautionary principle, the fulfillment of the obligation of 
the principal installment and/or interest made by the debtor affects gradually the improvement in credit quality for restructured loans.

Credit quality is determined based on an analysis of three assessment factors, namely business prospects, debtor performance, and capabilty to pay [13, 14]. Credit restructuring can only be carried out on the basis of written requests from customers with substandard, doubtful and congested credit quality categories. Regarding the application of the precautionary principle, each bank must have a credit restructuring guideline that contains the procedures and the setting for carrying out credit restructuring by including the analysis and documentation section. This is undertaken by always paying attention to the analysis, conclusions, and recommendations explicitly regulated in Article 9 of the Financial Services Authority Regulation Number 11/POJK.03/2015 concerning Provisions on Prudence in the Context of the National Economic Stimulus for Commercial Banks.

Credit restructuring carried out by providing additional credit must contain the purpose and use of additional credit as clearly as possible. Additional credit is not permitted to pay off arrears on principal and/or interest. If the loan restructuring results in the debtor's liability being greater, the bank may require new collateral. Adjustments to the repayment schedule reflect the repayment ability of the debtor. Details related to the transparency of credit requirements include financial agreements in credit agreements, such as plans for recapitulating debtor companies or the existence of clauses that banks can increase current interest rates with the ability to pay of debtors. Requirements that credit agreements and other documents relating to the implementation of credit restructuring must have legal force. The rules regarding the completeness of the documents required for the implementation of credit restructuring are regulated in Circular Letter No. 15/28/DPNP.

Appropriate observations at Bank Panin include a bank that has written policies and procedures regarding credit restructuring. What not all banks have are internal guidelines or provisions regarding credit restructuring based on Bank Indonesia Regulation Number 14/15/PBI/2012 concerning Asset Quality of Commercial Banks in Article 55 paragraph 1, namely "Banks must have written policies and procedures regarding credit restructuring."

In present study, we would state that conclusion to be drawn is that the relationship between written policies and procedures regarding internal credit restructuring at Bank Panin in handling credit restructuring is part of Special Asset Management (SAM) by:

a. Following up, such as through contacting the relevant customer through telephone or send a notice of debt obligations (Warning Letter 1, 2 and 3);

b. The bank, if ignored by the debtor, may carry out a customer visit service to collect directly to the address of the customer concerned or correspond to the customer to come face to face.

c. If the customer cannot deposit the installment fund shortage, the follow-up to the relevant bank is carried out to consider the existence of credit renewal which functions to cover collectibility by reducing interest rates and extending the loan term.

d. If the customer agrees with the idea of reducing interest rates and extending the term of the loan that will be used to alleviate the outstanding installments and other requirements fulfilled, the process can be carried out.

e. The initial process of submitting a restructuring is the same as the submission of new credit, so if each party has agreed on the number of loans, the period and total net funds received by the customer, then inputting through the bank system is carried out. 
This agreement serves to ensure legal certainty for the parties in granting credit, both in the context of preventive and repressive. Credit agreements, on the one hand, function to prevent defaults, and on the other hand, will be useful as evidence in the settlement of non-performing loans [18]. Rescue of non-performing loans with credit restructuring is carried out in several ways, i.e. reduction in loan interest rates, extension of credit term, reduction in interest on credit arrears, reduction of loan principal arrears, addition of credit facilities and conversion of credit to temporary equity participation [4].

Barriers in Credit Restructuring for Non-Performing Loan Debtors

The study on the barriers in credit restructuring can be seen from several perspectives according to researchers:

a. Barriers in the process;

According to Santoso, in the process of credit restructuring, there were a number of obstacles encountered, among others [19]:

- There is no openness between creditors and debtors. Such things cannot be separated from the antagonistic nature of the relationship between the two.

- There are limitations, both financial and staff who are experts in the field of recruitment.

- The lack of coordination between agencies involved as facilitators in restructuring.

b. Barriers from legal factors;

The restructuring policy is contained in scattered rules. In the provisions concerning banking there is no affirmation of whether credit restructuring is mandatory or merely an attempt to save credit. In the provision of Article 54 of Bank Indonesia Regulation concerning Asset Quality Rating for Commercial Banks, it is only determined that "Banks are required to apply accounting treatment for Credit Restructuring in accordance with applicable financial accounting standards." Accounting treatment for Credit Restructuring is applied to the recognition of losses incurred and recognition of interest income and other receipts. This can be a legal loophole for banks not to carry out restructuring of Non-Performing Loans.

c. Barriers in the implementation;

The credit restructuring program arises as a result of the provisions relating to the precautionary principle in the management of the Bank; the precautionary principle is incompatible with considering credit restructuring. Therefore, adjustments and a review of the prudential principle need to be carried out, especially regarding the deadline for withdrawals in the context of credit restructuring.

Systemically, the economic and monetary living conditions of a country can be seen from the high and low intensity of non-performing loans, causing a decrease in liquidity which results in a decrease in public confidence in the bank [20]. In the event that public trust decreases, the role of banks as intermediary institutions cannot function optimally. The implementation of the national economic recovery program began with the implementation of various steps for national banking restructuring carried out through the government guarantee program, banking recapitalization program and the implementation of bank loan restructuring. To detect this, Bank Indonesia regulates Commercial Bank Periodic Reports through Article 30 of the Banking Law. This reporting responsibility to Bank Indonesia is related to Bank Indonesia's responsibility in conducting supervision and guidance. Supervision and guidance of Bank Indonesia in terms of credit restructuring is useful if the rescue of non-performing loans is unsuccessful, the bank takes the following action in the form of write-off. The elimination of bad credit is carried out into two 
stages: conditional write-off and absolute write-off. Write-off claims is considered a bank loss [21]. The concept of write-off can be described as follows:

a. Write-off is an administrative action of the bank to delete a bad credit book from the balance sheet in the amount of the debtor's liability without removing the bank's claim rights to the debtor. The write-off is carried out on all funds provided and bound in one agreement. Writeoff is a conditional write-off and absolute write-off deletion. Conditional write-off is done by issuing all bad credit portfolios from the bank's books, but the bank continues to bill the debtor while in the absolute wite-off program, the bank no longer collects debtors [14].

b. Write-off is the act of the bank removing all debtor obligations that cannot be resolved. Policies and conditional write-off and absolute write-off procedures contain criteria, requirements, limits, authorities, and responsibilities and procedures for implementation. Conditional write-offs in the context of credit restructuring and credit settlement are intended for the sake of transparency to the debtor.

The conditional write-off and absolute write-off program is an effort to reduce the ratio of Non-Performing Loan and aims to improve the health of the bank [18]. Banks are required to have written policies and procedures regarding conditional write-offs and absolute write-offs. The policy must be approved by the Board of Commissioners. Procedures regarding conditional writeoffs and absolute write-offs must be approved at the lowest by the Directors. In addition, the Board of Commissioners must actively monitor the implementation of conditional write-off and absolute write-off policies.

Conditional write-off and absolute write-off can only be done after the Bank has made various efforts to recover the Earning Assets given. Banks are required to document the efforts taken as well as the basis for considering the write off and / or claim collection. Banks are required to administer data and information regarding Productive Assets that have been subject to conditional write-off and absolute write-off. If the conditional write-off and absolute write-off program is not successful, the bank as the creditor can resolve the problem of bad credit through litigation and non-litigation channels (alternative dispute resolution).

\section{Conclusion}

This study has examined the condition for implementing credit retructutrization for nonperforming loan creditors. Conclusions achieved are written in the following. The implementation of credit restructuring provisions has not been optimally implemented in the rescue and settlement of Non-Performing Loan in bank loans. This can be seen from the deviations made in the implementation of credit restructuring. Internal factors that have caused the optimal restructuring provisions are not thorough credit analysis from the bank, an indication of bad faith from the bank to ignore the restructuring process and ignorance of the customer that if there is a payment inability can be resolved through a restructuring proposal. External factors that have caused the optimal restructuring provisions that are restructuring policies as outlined in the Bank Indonesia Regulations and Financial Services Authority Regulations that often change.

The obstacles faced in the implementation of credit restructuring provisions in the rescue and settlement of Non-Performing Loans in bank loans can be viewed from legal factors, process 
factors, and obstacles in their implementation. The inhibiting legal factors are the external regulations in the Bank Indonesia Regulation and the scattered and frequently changing Financial Services Authority Regulations as well as internal arrangements in the relevant banks, namely regarding restructuring that does not yet exist or is not in accordance with the substance as mandated in Bank Indonesia Circular. In terms of process, the obstacle that occurs is the lack of openness between creditors and debtors. Such things cannot be separated from the nature of the antagonistic relationship between the two. The limitations of both financial and staff personnel who are experts in the field of recruitment and lack of coordination between the institutions involved as facilitators in restructuring are other factors of the implementation process. In terms of implementation, the obstacle that arises is that the precautionary principle is not in accordance with the consideration of credit restructuring. Therefore, adjustments and a review of the prudential principle, especially regarding the deadline for withdrawals in the context of credit restructuring, needs to be done.

From what has been found in this study, there is a few recommendations that we need, as authors, to convey. First, Bank Indonesia and the Financial Services Authority should not override policies regarding credit restructuring in the rescue of Non-Performing Loans. Each bank should have written policies and procedures regarding credit restructuring, have a special division that determines restructuring and distinguishes it from the credit submission division. The bank should provide training for its employees in increasing their knowledge of restructuring and prediction policies in measuring the ability and capability to pay through the debtor's business prospects as a source of income to carry out payments. The creditor should provide correct information regarding credit applications and interest rates and make anticipatory efforts before the occurrence of NonPerforming Loan by always monitoring the debtor's payment. Second, the debtor should study the credit agreement between himself and the creditor and have sufficient understanding in the banking sector which includes credit application requirements, payment terms, interest rates, payment calculation models and conditions if later he is unable to pay. Debtors, who in this case are bank customers, should have good faith to carry out achievements, be cooperative in every stage of the restructuring proposal, and provide correct information and data in order to reach an agreement in restructuring. If the debtor has participated cooperatively in terms of payment inability, the bank should provide an opportunity to restructure loans to customers before making a decision to sell collateral to cover the payment of credit.

Acknowledgements. The authors express the greatest gratitude to the organizing committee of the International Conference on Social Sciences (ICOSS) of Universitas Warmadewa for the great contribution that has been granted to the launching of this scientific script at EAI Publisher. Hopefully the ideas found in the paper can be additional theoretical and practical for many parties.

\section{References}

[1] Peraturan Bank Indonesia Nomor 15/2/Pbi/2013 Tentang Penetapan Status Dan Tindak Lanjut Pengawasan Bank Umum Konvensiona (2013)

[2] King, R.: The Receiving Bank's Role in Credit Transfer Transactions. Mod. Law Rev., vol. 45 (4) pp. 242-243 (1982) 
[3] Harrison, J.: One Function of the Savings Bank; Its Importance as a Lender or Distributor of Capital. LSE Libr. Jisc (2016)

[4] Zago, A and Dongili, P.: Credit quality and technical efficiency in banking. Empir. Econ. vol. 40

(2) pp. 537-558 (2011)

[5] Imaniyati, N, S.: Pengantar Hukum Perbankan Indonesia. Bandung. Refika Aditama (2010)

[6] Albanese, C, Brigo, D and Oertel, F.: Restructuring counterparty credit risk. pp. 1-27 (2012)

[7] Greinke, A.: Financial Restructuring and Credit Unions. Econ. Anal. Policy. vol. 28 (1). pp. 39-52 (1998)

[8] Amihud, Y et al.: Distressed Debt Restructuring in the Presence of Credit Default Swaps What Determines A Distressed Firm's Choice between in-and out-of-court debt renegotiation? A large body of theoretical and empirical research. vol. 48 (1) (2016)

[9] Supariyani, N.: Implementasi Ketentuan Restrukturisasi Kredit terhadap Debitur Wanprestasi pada Kredit Perbankan. J. Magister Huk. Udayana, vol. 5 (281-291). p. 11 (2016)

[10] Baldassarri, M, Paganetto, L and Phelps, E, S.: The Restructuring of Banks and Financial Systems in the Euro Area and the Financing of SMEs (2015)

[11] Susanti, D, O.: Penelitian Hukum (Legal Research). Jakarta. Sinar Grafika (2014)

[12] Faure, A, P.: Banking: An Introduction. Quion Institute (2013)

[13] Black, H, C.: Black’s Law Dictionary. St. Paul- Minnessota. West Publishing Co (1990)

[14] Hariyani, I.: Restrukturisasi dan Penghapusan Kredit Macet: Kenapa Perbankan Memanjakan Debitur Besar sedangkan Usaha/Debitur Kecil Dipaksa. Jakarta. Gramedia (2010)

[15] Baldassarri, M, Paganetto, L and Phelps, E, S.: The Restructuring of Banks and Financial Systems in the Euro Area and the Financing of SMEs. Palgrave Macmillan (2015)

[16] Forgione, A, F and Migliardo, C.: An empirical analysis of the impact of trade credit on bank debt restructuring. Econ. Polit (2018)

[17] Melnik, A, L and Plaut, S, E.: Credit quality, the intensity of regulation and the segmentation of debt markets. Res. Econ. vol. 52 (4) pp. 431-449 (1998)

[18] Crook, J, N, Edelman, D, B and Thomas, L, C.: Recent developments in consumer credit risk assessment. Eur. J. Oper. Res. vol. 183 (3). pp. 1447-1465 (2007)

[19] Santoso, W.: Kompleksitas Likuidasi Bank Dalam Perspektif Perusahaan. Buletin Hukum Perbankan dan Kebanksentaralan Bank Indonesia (2006)

[20] Andreou, E and Ghysels, E.: Quality control for structural credit risk models. J. Econom. vol. 146 (2). pp. 364-375 (2008)

[21] Ayayi, A, G.: Credit risk assessment in the microfinance industry: An application to a selected group of Vietnamese microfinance institutions and an extension to East Asian and Pacific microfinance institutions Ayayi Credit Risk Assessment. Econ. Transit. vol. 20 (1). pp. 37-72 (2012) 